\title{
Cannonball shadow in the lungs and pulmonary embolism in a young man
}

\author{
Ranjit Kumar Singh, Balamugesh Thangakunam, Barney Isaac, D J Christopher
}

Department of Pulmonary Medicine, Christian Medical College, Vellore, Tamil Nadu, India

\section{Correspondence to} Dr Ranjit Kumar Singh, drranjitsingh@yahoo.com
To cite: Singh RK, Thangakunam $B$, Isaac $B$, et al. BMJ Case Rep Published online: [please include Day Month Year] doi:10.1136/bcr-2012007541

\section{DESCRIPTION}

A 20-year-old non-smoking man presented with a history of chest pain, cough, loss of weight and appetite for a 3-month duration. Prior to presentation, he was diagnosed at a local hospital as having pneumonia and was treated with oral and intravenous antibiotics. Since the patient's symptoms did not abate with treatment, he was referred to our centre for further management.

On physical examination, his vital signs were within normal limits. He was not in obvious distress. There was a hard right-sided testicular swelling. His left testis was normal in consistency. There was no evidence of a hydrocele. The rest of the systemic examination was unremarkable.

\section{Laboratory findings}

His blood counts and routine serum biochemistries were normal. His serum lactate dehydrogenase (LDH) was elevated at $3492 \mathrm{IU} / \mathrm{L}$ (normal up to $160 \mathrm{IU} / \mathrm{L}), \quad \beta$-human chorionic gonadotropin ( $\beta$-HCG) was $89.29 \mathrm{mIU} / \mathrm{mL}$ (normal up to 5) and $\alpha$-fetoprotein was $14 \mathrm{IU} / \mathrm{mL}$ (normal up to 5.5 ). Serum antineutrophilic antibodies were not detected. The Mantoux test and sputum smear and culture for Mycobacterium tuberculosis bacilli were negative. His chest X-ray revealed multiple nodular lesions of varying sizes without air bronchogram (figure 1). CT showed large nodular discrete lung masses, the largest in the right upper lobe measuring $7.5 \times 5 \mathrm{~cm}$ (figure 2). Some masses showed heterogeneous enhancement with areas of necrosis. There were filling defects suggestive of thrombus in the right pulmonary artery and the right descending pulmonary artery (figure 3). The differential diagnoses considered were metastatic tumour, infections like tuberculosis, ${ }^{1}$ multisystem disorders like Wegener's granulomatosis ${ }^{1}{ }^{2}$ and rheumatoid nodules with pulmonary embolism, multiple large, well-defined cannonballs (primarily with choriocarcinoma and seminoma). Thus, germ cell tumour was thought to be the most likely primary aetiology. ${ }^{3}$ Tumour emboli are not infrequent, but are often microscopic ${ }^{4} 5$ and are missed frequently even with a CT pulmonary angiogram. ${ }^{6}$

The tumours that are frequently associated with tumour emboli are hepatomas, breast and renal carcinoma, gastric and prostatic cancers and choriocarcinomas. $^{45}$ Since one of the lung nodules on the left side was peripherally situated, adjacent to the chest wall, an ultrasound-guided biopsy was performed. The histopathology revealed pleural tissue infiltrated by a tumour composed of sheets and cords of polygonal cells exhibiting increased mitotic activity, moderate nuclear pleomorphism, hyperchromatic nuclei and moderate amounts of an

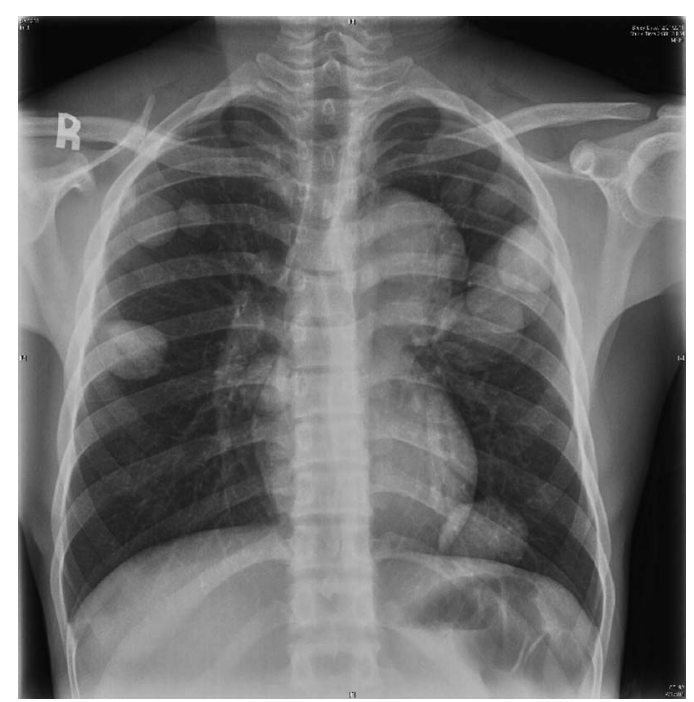

Figure 1 Prechemotherapy chest X-ray.

eosinophilic cytoplasm. Immunohistocytochemistry showed positivity for placental alkaline phosphatase, $\alpha$-fetoprotein and CD30. The pathological diagnosis showed metastatic germ cell tumour with a predominantly embryonal carcinoma pattern. The patient received four cycles of chemotherapy with cisplatin and etoposide and also underwent right inguinal orchidectomy. He was also started on low molecular weight heparin for pulmonary embolism. A follow-up CT of the chest after four cycles showed that the masses had resolved or reduced significantly in size with areas of scarring and cavitations (figure 4).

\section{DISCUSSION}

Germ cell tumours of the testis occur very rarely. Their prevalence is about $1 \%$ of all malignant neoplasms. Although malignant extragonadal germ cell

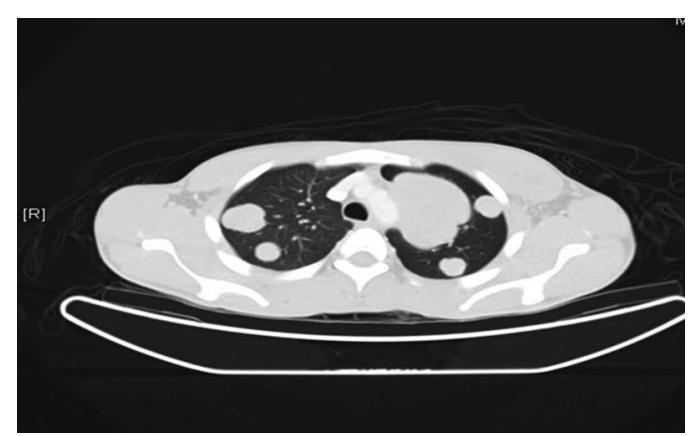

Figure 2 Prechemotherapy CT of the chest with multiple cannonball lesions. 


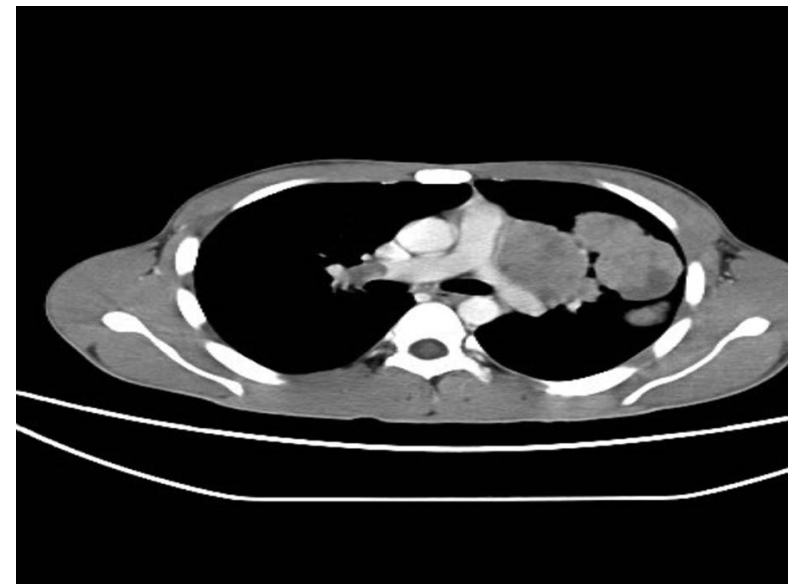

Figure 3 Prechemotherapy CT of the chest with pulmonary embolism in the right pulmonary artery.

tumours of the lung are extremely rare, their recognition is of clinical importance because of their curability.

This is the role model treatable tumour, which is chemosensitive and curable. Its cure rate is about $80 \%$ in disseminated diseases and 98\% in localised diseases. Malignancy in general is a risk factor for pulmonary embolism, and this association is more important with germ cell tumours. There are two risk factors described in the literature which can predispose to pulmonary embolism in germ cell tumour. ${ }^{7}$ The first is a high body surface area and the second, an elevated serum LDH before chemotherapy. ${ }^{7}$ In our patient, the LDH level was very high, but his body surface area was normal at $1.48 \mathrm{~m}^{2}$. Participants with no adverse factors had a $4 \%$ risk of thromboembolism. On the other hand, those with at least one risk factor had a $26 \%$ chance of thrombosis. ${ }^{8} 9$

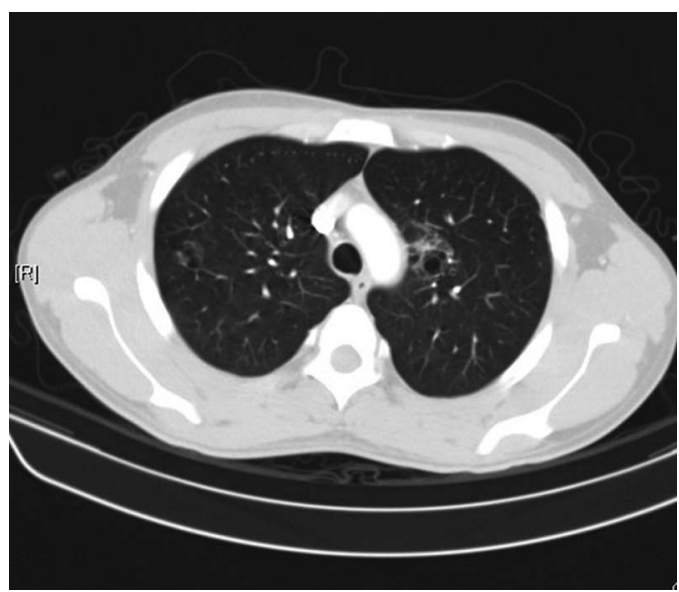

Figure $4 \mathrm{CT}$ of the chest post chemotherapy.
The serum $\beta$-HCG is reliable as well as being a useful assay in the diagnosis and management of seminoma. ${ }^{6}$ In our index patient, $\beta$-HCG was high, and after chemotherapy its value became normal. Choriocarcinoma is a rare malignant tumour developing after pregnancy, with frequent metastases to the lungs; however, when the tumours embolise into the pulmonary arteries, they resemble pulmonary thromboembolism, making correct diagnosis difficult. Physicians must suspect this disease in cases of pulmonary embolism in women. ${ }^{10}$

\section{Learning points}

- Multiple round lesions in a young patient is a rare, metastatic malignancy that should figure in the differential diagnosis.

- Testicular examination may give a clue to the diagnosis in such patients.

- Germ cell tumours present with multiple large, well-defined cannonball lesions in the lungs.

- It is important to diagnose germ cell tumours because of their good response to treatment and potential curability.

- Germ cell tumours are associated with pulmonary embolism.

- Patients with malignancy who develop pulmonary embolism need long-term anticoagulation.

Competing interests None.

Patient consent Obtained.

Provenance and peer review Not commissioned; externally peer reviewed.

\section{REFERENCES}

1 Kayser K, Donnwald D, Zink S, et al. Small pulmonary lesions-a challenge for thoracic surgery? ScientificWorldJournal 2001;1:906-13.

2 Fraser RG, Pare JA, Fraser RS. Multiple pulmonary nodules with or without cavitations. Diagnosis of diseases of the chest. 3rd edn. Philadelphia: WB Saunders, 1991:3074-9.

3 Boitsios G, Bankier AA, Eisenberg RL. Diffuse pulmonary nodules. AJR Am J Roentgenol 2010;194:W354-66.

4 Winterbauer RH, Elfenbein IB, Ball WC Jr. Incidence and clinical significance of tumor embolization to the lungs. Am J Med 1968;45:271-90.

5 Kane RD, Hawkins HK, Miller JA, et al. Microscopic pulmonary tumor emboli associated with dyspnea. Cancer 1975;36:1473-82.

6 Chan CK, Hutcheon MA, Hyland RH, et al. Pulmonary tumor embolism: a critical review of clinical, imaging, and hemodynamic features. J Thorac Imaging 1987;2:4-14.

7 Piketty AC, Flechon A, Laplanche A, et al. The risk of thrombo-embolic events is increased in patients with germ-cell tumours and can be predicted by serum lactate dehydrogenase and body surface area. Br J Cancer 2005;93:909-14.

8 Miskovska V, Ondrus D. Thromboembolic diseases and testicular germ cell tumors, Bratis/ Lek Listy 2010;111:166-7.

9 Weijl NI, Rutten MF, Zwinderman AH, et al. Thromboembolic events during chemotherapy for germ cell cancer: a cohort study and review of the literature. J Clin Oncol 2000;18:2169-78.

10 Tajiri S, Ozawa $\mathrm{H}$, Komatsu M, et al. A case of choriocarcinoma of suspected lung origin manifesting pulmonary embolism. Nihon Kokyuki Gakkai Zasshi 2008:46:1029-33. 
Copyright 2013 BMJ Publishing Group. All rights reserved. For permission to reuse any of this content visit http://group.bmj.com/group/rights-licensing/permissions.

BMJ Case Report Fellows may re-use this article for personal use and teaching without any further permission.

Become a Fellow of BMJ Case Reports today and you can:

- Submit as many cases as you like

- Enjoy fast sympathetic peer review and rapid publication of accepted articles

- Access all the published articles

- Re-use any of the published material for personal use and teaching without further permission

For information on Institutional Fellowships contact consortiasales@bmjgroup.com

Visit casereports.bmj.com for more articles like this and to become a Fellow 